\title{
THE FALL OF ORMUZ: AN INCIDENT IN THE ANGLO-IBERIAN CONTEST FOR THE CONTROL OF TRADE IN THE EAST
}

\section{Lawrence James Nielsen}

The Portuguese garrison at Ormuz in the Persian Gulf mutineed on 22 April 1622. The mutineers forced their officers to surrender to the combined Persian-East India Company forces, ending one hundred years of Portuguese dominance in Persian waters and the Indian Ocean. Within thirty years, a few ruined, deserted fortresses were all that remained of the Portuguese Persian dominions. The capture of Ormuz was not only an important event in the drama of Portuguese overseas expansion, it was also a significant part of the competition inherent in European mercantile imperialism which saw the flags and navies of European monarchies following merchant companies to overseas competition and wars throughout the seventeenth and wighteenth centuries. For the eastern world, Ormuz was the example of how native princes could use the European lust for trade to throw off the yoke of European dominance, or at least keep the Europeans at bay. Above all else, the reactions of the English and Spanish monarchs and their counselors demonstrates how competition for trade influenced the real politics of the epoch: marriage and treates could be abandoned if success could be had at the expense of a rival.

The Portuguese exploded into the Indian Ocean-Arabian Sea trading area in the last years of the fifteenth century. They found their old enemy, the Moslem, in control of trade and dominant in religion throughout this quarter of the world. While some Portuguese adventurers sought for pepper, spices, and conquest further east, many remained to fight their ancient enemy from Africa to India. In the process, they cained control of many important ports and trading centers from southern Africa to southern India. They were too few in number, however, to completely subjugate the peoples of Africa, Persia, Arabia, and India, though they were strong enough to dominate commerce. They forced most traders from India to Persia and Arabia to either use Portuguese vessels or pay for the protection of the Portuguese fleet and the privilege of trading in Portuguese controlled waters. Several of these fortified trading centers became sites of permanent Lusitanian populations as the Portuguese adventurers either settled their families or married with the native peoples. Of all the Portuguese strongholds along the shores of the Indian Ocean, only Goa outranked Ormuz in importance. 
Prior to the arrival of the Portuguese, the island of Ormuz was a place of little importance in the Persian Gulf. The "king" of Ormuz was forced to become a vassal of Portugal and the Portuguese turned the almost uninhabitable island into a large trading center and fortress. By 1600, Ormuz claimed a population of around 400.000. All of India's trade with Arabia and Africa was carried to Ormuz where it was transferred to coasting vessels to be carried to smaller forts. It was here that duties were collected and Moslem pilgrims to Mecca were taxed. ${ }^{1}$

The geographical location of Ormuz made it a natural trading center and naval stronghold. The climate of the region, however, was a liability. Little or no rain fell on the island. Almost all food, water, and firewood came from the mainland or other islands. The weather was often so hot that the inhabitants slept out of doors because their dwellings were uncomfortably warm. The weather and the lack of suitable local building materials made it difficult to maintain the fortifications on the island in good repair. The Portuguese, therefore, allowed the fortifications to fall into disrepair and depended upon their naval superiority in the region for protection as well as for provisions of food, water and fuel. ${ }^{2}$

The trade from Ormuz was largely luxury goods. Silks, pearls, horses, and precious metals were sold from Persia through Ormuz to her trading partners. When the English arrived upon the scene in the first quarter of the seventeenth century, Persia was attempting to throw off the yoke of the Turks on land and the Portuguese at sea. She also sought new markets for her silks. The Persians, therefore, welcomed the arrival of Portugal's rivals for trade and commerce. The Portuguese did not.

The problem was complicated because Portugal had been part of Spain for twenty years and therefore regarded the Dutch and English as de facto enemies. And, given the strategic geographic position of Ormuz, any enemy or competitor would of necessity be forced to either wrest it from Portuguese hands or neutralize it by locating a defense base in the same area. The appearance of the Dutch and English in the Indian Ocean ports posed a considerable threat to the sparse Portuguese establishment in the eastern part of the world. The royal government and its people stood to lose more than important revenues. In good years, 1700 to 1800 tons of pepper were laden in $\mathrm{G}$ oa for shipment to Lisbon. These shipments depended upon Ormuz for defense. The annuan revenues paid to the Portuguese crown from the license fees collected at Ormuz came to over 160.000 escudos; at Diu, over 100.000 escudos; and at Goa, over 160.000 escudos. The total crown revenues from prizes, customs duties, and tribute extorted form eastern principalities exceeded 1.000 .000 escudos per year. ${ }^{3}$ The Portuguese merchants gained even more in the east, though possibly more important to many Portuguese than the wealth from the East were the immense pride and national prestige they sained from their conquests and holdings and from their missionary successes. The wealth, the Glory of the conquests, the length of their dominance in the East, and the pleasure of God over their religious work, which they believed was manifested by their continued success, all combined in the Lusitanian mind to justify and legitimize their claims to an exclusive right to the wealth of the Indies.

The appearance of the English and Dutch off the coasts of Africa, Arabia, India, and the rest of Asia, therefore, posed a threefold threat to the Portuguese. 
Understandably, the designs of the northern interlopers upon the Portuguese commercial monopoly was of primary importance. Yet it was of no more importance to the Portuguese, especially those with family ties in the East, than the dangers the feared alliances between the English and the Dutch and their enemies would pose, nor the threat the meterodoxy of the newcomers presented to their religious establishments. The events that followed justified the Portuguese fears.

The English came to the East in search of wealth to enrich their kingdom. When they arrived there, they objected to the Lusitanian control of the Asian-European trade, and cominance in the so-called "country trade" or inter-east-Indies trade. Once the Portuguese opposed their attempts at peaceful commerce, the English turned to force to press their "rights" as a nation to trade. A lust for commerce and treasure was combined with a sense of national duty. From the date of the first voyage of the East India Company in 1599 until 1613, the English merchants struggled for a foothold in the country trade of the Indian Ocean as well as a place in the European-East Indies trade. This was sound mercantilism. It was important to establish oneself in trading patterns outside those of one's nation. The profits from such commerce could be sent home as goods to be traded elsewhere in Europe, as precious metals and stones to enrich the national treasury, or as raw materials or semi-finished industrial goods to foster or sustain national industry. Once the English had their foothold, they sought to monopolize as much of the trade from and in the East as possible: alsc sound mercantilism.

The first two voyages of the English East India Company aimed at trade with the Spice Islands. Trade with India, Persia and Arabia was ignored for the most part. When the second voyage returned home with its valuable cargo, the company began preparations for a third voyage. From information gathered on the first two voyages, the company had learned that Indian cloth could be traded profitably in the Maluccas and in Sumatra and Java. Instructions were accordingly given to Captain Keeling, the commander of the third voyage, to experiment with trade at Aden and in Guzarat (Cambay Gulf), and then sail to the proven areas of profitable trade in Sumatra. This voyage (April 1607 - April 1610) was significant for two reasons. After a tedious passage, Keeling reached Cambay and left William Hawking, nephew of Sir John Hawking, in Surat in August 1609 with a letter from James I to Jahangir, the Great Mogul. This embassy began the English attempt to place a factory on the west coast of India to the north of Goa. As a result of Keeling's commercial triumph, the company pushed James to give them a perpetual charter to replace the fifteen-year limit imposed by Elizabeth. It was granted. Moreover, while the third voyage was sailing for the Cape of Good Hope, the company prepared a fourth voyage. Instead of waiting for the result of a voyage to be known before preparing the next, the company began sending yearly voyages. In the voyages that reached India between 1608 and 1613, there was constant friction with the Portuguese in Cambay Gulf. The Portuguese, by threatening reprisals against the fearful native population, successfully blocked the sixth expedition in its attempt to trade in the Cambay ports. This expedition, however, recovered its losses by taking Portuguese and Guzarat prizes at the entrance of the Red Sea. These hostile actions were followed by the attempts of Thomas Best to trade at the Cambay ports. In several brilliant encounters, Best defeated a superior Portuguese fleet. In spite of the news of the previous expedition's depredations in the Red Sea area, which reached Cambay while he was 
present, Best was able to secure permission to establish a factory at Surat, a promise that no reparations would be paid for past acts of piracy, the right to maintain an agent or ambassador at the capital city, a custom duty of no more than 3-1/2 percent, and a promise of protection for the English and their goods in India. When Best sailed for Bantam in Sumatra, the English had a foothold and factory in India. ${ }^{5}$ Furthermore, the English had a knowledge of and entrance into the country trade carried on between India, Persia, Arabia, and the Red Sea.

While Keeling, Middleton and Best struggled for the right to trade in India, a Persian Ambassador left Persia for Europe, looking for any Christian power that would ally with the Sham Assas against the Turk. With this alliance came a promise of the silk trade that passed from Persia to Constantinople and other Turkish ports into Europe. The Persian envoy was Robert Sherley, one of the three sons of Sir Thomas Sherley, who left England in search of wealth and to avoid the consequences of declining fortunes in England. Sherley left overland from Persia on 12 February 1608 and visited the Emperor, the King of Poland and the Pope among others. Reaching the court of Philip III, where his brother Anthony served, Sir Robert was not well received. After fruitless negotiations, he prepared to depart for Holland and then to England. The Spanish tried and failed to prevent his passage to their northern rivals. They only managed to delay his passage until June 1611. During his long stay in Madrid, Sherley was adequately subsidized by the Spanish crown, but painfully treated due to false ambassadors from Persia who denounced him as a froud. Worse, his own brother conspired with Philip's counsellors against Sir Robert's person.

Sir Robert was not too well received in England, either. In spite of Sir John Digby's recommendation of him and his projects, Sherley found James unwilling to grant him any subsidies. The East India and Levant Companies, while competing for the rights to trade in Persia, refused to subsidize or to cooperate with him. Moreover, being Catholic, Sherley incurred the emnity of Archbishop Abbot. Nevertheless, James I and the Secretary Cottington refused to believe the calumnies cast about by Abbot and the Spanish ambassador to England, Don Alfonso de Velasco, and finally listened to Sherley's schemes for capturing the Persian silk trade, though the king's credence was not enough to overcome the opposition he faced. January 7, 1613, Sir Robert and his retinue of fifteen, including Teressa, his Circassian wife, slipped quietly out of Gravesend aboard the Expedition. ${ }^{7}$

The Sherley embassy was not landed in Persia as the crew of the Expedition planned. Instead, after marrowly escaping death at the hands of natives who had rebelled against the Shah, Sherley was carried to Duil-Sinde where he and the English suffered at the hands of the Portuguese and the Moqul's governor. At one point, a band of Portuguese soldiers attacked and burned the home in which the Sherleys were living and they narrowly escaped with their lives. After other hardships, they visited the Moqul's court where their complaints were heard and the governor of Duil-Sinde was sent to prison in chains. The Sherley embassy, that is, those few who still lived, returned to Persia by caravan. While in India, Sir Robert provided the company's merchants with ${ }^{2}$ description of the ports of the Persian Gulf. This proved useful to the factors when they extended their trade to Persia. ${ }^{8}$ 
Sir Robert's advice to the company's factors in India that the company either extend its trade to Persia or lose it to the Dutch came at the proper moment. It had been only a few months since Captain Thomas Best had gained his impressive victory over the Portuguese. The English had a factory in surat and were searching for ports to trade Indian and English articles for the luxuries desired in India. The factors resolved to send representatives overland to the Shah's court at Ispahan, to sue for trading privileges. This embassy left Asmere March 17, 1614. While the caravan in which the embassy, composed of Richard Steele and John Crowther, wound its way through the desert and steppe between India and Persia, the old Persian emnity against the Portuguese caught flame and helped prepare the way for a successful conclusion of the English design.

In early 1614, the Portuguese captain at Ormuz ordered the capture of a coasting vessel bound for Ormuz. The seventy merchants on board the vessel were cruelly sutchered and their coods carried off as spoils. Their families begged the Shah and the governor of Shiraz for vengeance. The Persian first reduced the fortress of Comoran in Bande (now Bandar Assas). Seventy of the defenders were beheaded and the remainder enslaved. The Island of Khisme and the Arabian town of Jalpha fell in succession. Throughout the long seiges of these places, the Portuguese at Ormuz did nothing in their defense. As a result, Ormuz lost its principal sources of food, water, and fuel. ${ }^{9}$

While the Persian forces were defeating the Portuguese, the Shah ordered Robert Sherley to make another diplomatic visit to Spain. Sir Robert pleaded with the Shah not to send him, but relented when the Shah sent one of the barefoot Carmelite friars to speak for him in Spain and held the remaining friars at his court hostage against the safe return of Sir Robert. The Shah also gave in to Sherley's plea that all Portuguese slaves and prisoners be put into his hands to be returned to Ormuz.

While Sherley was conducting forty-five Portuguese prisoners to Ormuz, he met the English East India Company representative Richard Steele, who had arrived at Ispahan on September 15, 1615. On September 19, Sir Robert secretly presented the Englishman to various Persian officials. The Grand Vizier prepared three firman or contracts; one for Crowthers to carry to Surat, one for Steele to carry to England, and a third to be sent to the governor of Jask. With the firman, the English gained the privilege to trade in Persia and a promise of a factory at Jask. The firman carried by Steele and presented to James I on his arrival in England in May 1616 read as follows

Firman or command given unto all our subjects, from the greatest unto what degree soever, unto the Souf-Basha or Constable of our country, to kindly receive and entertain the English Franks or nation, at what time any of their ships or shipping shall arrive at Jasques, or any other of the ports of our kingdom: to conduct them and their merchandise to what place or places they themselves desire: and that you shall see them safely defended about our coasts, from any other Frank or Franks Europeans whatsoever.

This I will and command you so to do, as you shall answer to the contrary. Given at our Royal citie... 10

Richard Steel's success was diminished by the arrival of Sir Thomas Roe, King James's ambassador to the Eastern world. Roe had been chosen at the request of the East India Company. The company felt that the king needed to send a royal ambassador to 
India and Persia to arrange formal treaties between England and the courts of the Great Mogul and the Shah. Treaties arranged amongst the three crowns would legitimize the company's trading position. No longer would the Iberians or the Dutch be able to present a better legal position for trade than the English. Moreover, the Portuguese had been defeated by the Persians, English, and Indians. Their commerce was approaching the point of ruin. The company's governors felt that it would be advantageous to treat with the oriental potentates while the Portuguese were weak and in disfavor.

Carrying letters from James I to the Great Mogul and with various letters of instruction, Ambassador Roe and his retinue of fifteen people set sail for the East on February 2, 1615. He arrived in India after an uneventful, six-month voyage. After landing at Swalley (Cambay), Roe set out on his two month journey to Jahangir's court at Asmere, arriving there on December 23, 1615. From that time until his departure from India in 1619, Roe directed the trade and negotiations in Persia from whatever house or tent he lived in as he followed Jamangir's progress.

Roe received his first information on the success of Steele and Crowther's mission to Persia on February 10,1616. He was incensed with their unwitting encroachment upon his ambassadorial duties, and found it difficult to forgive them or Robert Sherley for aiding them. In his letters written upon receipt of the news, Roe did not try to undo the gains in Persia. Rather, he told the company not to be too optomistic about the alleged success. Jask, he argued, was a poor harbor and too close to Ormuz to be of great importance as a trade emporium. Nevertheless, he cautioned the company to beg the king to have his representatives in Spain insure that any treaties drawn up between Sir Robert Sherley and Philip III did not hinder English trade at Jask. Roe then dispatched a letter to Shah Abbas urging him to throw his country open to free trade, refuse Portuguese entreaties to grant them a monopoly, and to remove their dominance from his coasts.

While Roe turned to attend to his mission to Jahangir's court, the merchants at Surat met. They were angry with Roe for his attempt to dominate their activities. After a lengthy meeting, the merchants decided to send Edward Connock, the chief merchant of the fleet, to Persia. Connock left for Persia in November 1616 aboard the James. The English ambassador again felt his dignity attacked. A letter written with the aid of the Persian ambassador to the Great Mogul was sent off to Ispahan, explaining that the English came to experiment with trade in Persia while begging that the Shah not judge their humble beginnings too harghly. Roe believed the merchants had sent inferior trade goods.

Meanwhile, news or Roe's problems with the factors reached England. James I and the company sent fresh correspondence giving Roe specific authority to carry on the negotiations with the Shah, teeling the factors to follow Roe's command. Roe was also instructed to gain all the knowledge possible about the silk trade in Persia, and to request that the Shah agree to as low a customs duty as possible, assign a safe port where the merchants would trade without fear of weather or enemies, and establish prices for silks. Roe was also granted permission to disavow any of the activities or agreements made in Persia.

After receiving the new instructions from the king and the company in the autumn of 1617, Roe asked Captain Prins and Thomas Keeridge to decide if a ship should be sent 
to Persia to find out what had passed there; and if they so decided, he agreed to send a commission empowering Connock to negotiate with the Shah. The merchants decided in the affirmative and the Bee was dispatched for Jask and returned in January 1618 with the information requested. ${ }^{11}$

Connock and the factors destined for Persia had landed at Jask in December 1616. They made tieir way to Shiraz where they were detained, partially through the activities of the Portuguese, and then to Ispahan, arriving there in May 1617. Dissensions grew among the English and did little to help their efforts. Connock in his letter of May 15, 1617 , complained of the liscentiousness and greedy, wasteful conduct of one factor. Trade looked promising and, after declaring that the English could purchase over 500 bales of silk there per year, Connock noted that his purpose was to ruin the whole of the Portuguese trade at Ormuz. Moreover, he wrote that he planned to go to the war front where the Shah faced the armies of the Turk, to bue for the right to fortify Jask. He reported that he had already settled factors at Shiraz and Ispahan and intended to establish another at Jask in the coming year.

In August 1617, Connock reported that he had met with the Shah in the presence of an Augustinian friar representing the king of Spain. The friar charged that Connock had manufactured his letters from the king of England. Shah Assas examined his credentials and decided they were valid. When asked why he came, Connock responded that he came to discuss the proposals of "amity, trade, and commerce" presented by Robert Sherley years before. After further discourse, the Shah promised that the English could have Jask as a port and that they could trade free from harm anywhere in his kingdom. Connock advised the Shah that it would take at least three or four years before the English would be able to trade for any sizable amount of silk. Six days after his last visit, the articles allowing the English trading privileges were signed and Connock began preparing to return t to Ispahan. On the way from Ispahan to Jask, Connock sickened and died on December 24, 1617.

Since Edward Connock had failed to secure all that the English desired, Roe appointed thomas Barker and Edward Monox then in Persia to treat with the Shah for additional concessions. In April 1618, the embassy reported that while Don Garcia de Figueroa y Silva was trying to persuade the Shah to embargo all trade with England, as well as to restore the possessions captured from Portugal in 1614, the Shah remained friendly towards the English. ${ }^{12}$ In June 1618, Barker proposed a treaty enumerating a long list of favorable privileges for the English. Unfortunately for the English, Barker's druken behavior brought disgrace upon himself and the company. He and the proposed treaty were dimissed from the Shah's court. Fighting continued among the factors while they severally tried to improve the company's trading position in Persia. They were not above trying to cross one another's accomplishments in order to claim the glory of bettling favorable trading concessions for the company. In the latter part of 1618, Roe received the distressing news of their conduct and disunity. He was preparing to depart for home and had to leave conditions as they were, contenting himself with the knowledge that the Royal Anne, his passage home, carried a large cargo of Persian silk. The cargo was sold at a high price in England and led the company to calculate a projected 50 to 90 percent profit on the Persian trade per year. ${ }^{13}$ 
Through the years of 1619 and 1620, Barker and Monox attended the Shah's court presenting him with as lavish presents as their founds would allow. Their attempts at trade were disappointing. The Shah ordered an unfavorable exchange rate for the coin the English bartered with and silk prices rose higher than expected. In spite of the fact that the Spanish ambassador still in Persia did everything possible to avoid contact with them, his presence made the factors uneaby. They knew he asked the Shah for their exclusion from the silk trade and their expulsion from Persia. They did not know that the Shah turned a deaf ear to the ambassador because he would make no concrete proposals for a joint Hispano-Persian attack on the Turkish Empire. Moreover, the Shah was not disposed to expell the English whom he viewed as a balance to the Portuguese threat to his coastal cities. The English were further alarmed by the growing Portuguese naval and land forces at Ormuz. Speculations varied about the import of preparations on the desert island. The Portuguese were increasing their naval and military strength because they feared that the English would unite with the Persians to storm Ormuz. It was the fear of an English raid on their shipping that prevented the Portuguese from carrying Don Garcia de Silva y Figueroa to Goa. The late 1619 monsoon was missed and the unfortunate ambassador spent another winter in the East. The fear of an English attack subsided when it became plain that the English meant only to trade.

The first monsoon from Goa to the Persian Gulf in 1621 blew Ruy Freyre de Andrade and a fleet of Portuguese warships into Persian waters. Ruy Freyre landed at Khisme and took the Island back from the Persians on May 21, 1621. Part of the same fleet which took Queixome also tarried a while off Jask to prevent the Hart, London, and Roe Buck from trading there. The Portuguese failed, and after a bitter and sloody sea battle off Jask, the Hart, Roe Buck and two other ships sailed for the Red Sea to wait the next monsoon to Europe. On the passage to the Red Sea, they met two larger ships, one of 250 tons loaded with rice and other supplies for Ruy Freyre's fleet. They failed to make the Red Sea and waited out the contrary winds off the coast of Arabia. During their wait, the Portuguese from Mascate and their Arab allies made life uncomfortable. When the winds changed, instead of sailing for England, they fell in with other English ships and sailed for India to take revenge upon the ships of princes who offended them. The eleven English ships stayed off the Indian coast until late November. Then, the Eagle and Hart sailed for England and the remaining nine for Persia. The fleet reached Jask December 14 and received word that it was to sail to Kumistak to the south. There, the fleet was advised that for the past seven months the Persians had besiesed Khisme. The Khan of Shiraz and the Shah had sent an ambassador to tell the English that they either join with the Persians to drive the Portuguese from the gulf, or lose all their trade in Persia.

A council was held among the factors, including Monox, who had been releived of his position because of disgraceful conduct. Monox was persuasively for the leaque with Persia and the council decided to join the siege at Khisme. Dispatches were prepared for England to explain that circumstances forced their hand. The mutinous elements of the ships' crews that objected to taking part in the hostilities were placated by promises of double pay and threats of severe punishment if they refused to go to battle.

By the agreement made with the Shah, the English were to lend their sea power, which the Persians needed to bring their war against the Portuguese to a successful 
conclusion, in return, the English were to receive half the spoils from Khisme and Ormuz, toll-free trade with Persia, half the customs receipts collected at Ormuz, a promise that the persians would pay half the English expenses incurred in the siege, and a promise that all Christians captured by the Persians would be delivered to them.

The fleet set sail for Ormuz and arrived at Khisme, which lies within sight of Ormuz, January 22, 1622. The Captain of Ormuz sent a message to Ruy Freyre asking him to abandon Khisme for Ormuz. But Ruy Freyre could not; his fortress at Khisme was completely encircled by the combined Persian land forces and ships of the East India Company. The Portuguese asked to parley, but the talks came to nothings because the English could offer no protection to Ruy Freyre's native allies. Though the English finally secured the word of the Persian general that the allies would be given safe passage, the Portuguese leader arqued that he could not trust verbal promises of the Persians. The English batteries set up on shore pounded the fortress. Their weakened position combined with the fear of what the Persians promised to do to the wives, daughters, and sons of the Portuguese in Khisme to produce a mutiny within the fort. Ruy Freyre surrendered to the English on February 1, 1622. The Portuguese commander was sent by ship to Surat where he conveniently escaped. The Portuguese soldiers and few families were transported to Mascate and the wounded sent weaponless to Ormuz. The native allies were turned over the the Persians who abased them, then slaughtered them.

The Anglo-Persian allies then repaired to Bander Assas to prepare for the siege of Ormuz. On February 9, the English anchored off Ormuz. The next day, under the protection of the English fleet, the Persians transported several thousand soldiers to the island. The entire population of Ormuz fled within the walls of the fortress and began consuming the scanty food and water supplies of the castle. The eight years of irregular sources of supply since the fall of its Persian suplly bases in 1615, and the growing English menace to their sea contact with Goa and Africa told its tale. Again the persian promises of turning the Portuguese women and children over to the Persian soldiers for entertainment out into morale. Starvation, thirst, disease, and fear led to mutiny and on April 22 and 23, 1622, the Portuguese at Ormuz surrendered and the fortress was occupied by the Persians and the English.

Some of the English conducted the Portuguese inhabitants to Mascate and Sumar in India. The rest prepared reports to be sent to England. The company needed to be advised to the outcome so that it could prepare its defense against the Spanish diplomatic offensive that coold come in reaction to the capture of Ormuz. ${ }^{15}$

Almost as soon as the fortress at Ormuz was surrendered, the English and Persians fell out over the spoils. The English "half" came to $£ 18,000$ and a few cannon. The promised subsidies were reduceb by excessive charges for food and water provided the English during the siege. The English in Persia were smarting from fear of the reaction in England and the base dealings of their allies. They remembered that Sir Walter Raleigh had angered Spain and lost his head for less than they had done, and they had almost as little to show for their efforts. The surprised Persians, therefore, wondered at the emphatic but polite rejection of a proposed Anglo-Persian adventure against Muscate. The English in Persia began trying to drive a profitable trade against rising hostilities at the Persian court. By 1623, suggestions were made that the factory in Persia be abolished 
because it failed to produce a profit. Yet the English held on, partially for fear that the Dutch would drive a successful trade in Persia to their disgrace, partially because they needed the goods and ports of Persia to support their trade elsewhere in the East and Europe.

The ill news of the Portuguese losses at Ormuz produced mass despair at Goa. The situation worbened when neighboring Indian princes talked of taking advantage of the weakened Portuguese position. The senate at Goa hit upon a strategem to raise morale, to impress the native princes, and help the soldiers to face the ever-present danger of attack from the combined Anglo-Dutch fleets of defense. ${ }^{16}$ False messages were manufactured and received of Ruy Freyre's miraculous defeat of the English at sea and the Persians by land. Ormuz, the tale went, was retaken through the glorious feats of Portuguese arms and Jesuit Miracles. In their isolation from the world beyond India, the wives, children and parents of soldiers serving in Persia, old men who had once fought for the glory of Portugal and the "temple of Catholic fame," native Christians who feared to see their heroes vanquished, at first believed the awful tale of divine intervention and victory, but eventually the true state of Ormuz became known in Goa. ${ }^{17}$

The English factors in India, Sumatra, and elsewhere voiced almost universal disapproval of the events at Ormuz. In their December 10, 1622 report to President and Council at Batavia, the factors at Surat condemned the capture at Ormuz as a rash undertaking which dishonored the English nation because the town and castle were taken by surprise, and after their adventures, the English received little spoil or benefit from the conquest. President Furbland and the Batavia Council wrote to the Surat factory on April 17, 1623, and reported that, while the Dutch were amused at the fuss over Ormuz, they feared the reaction in Europe when the king of Spain heard of the fall of Portugal's jewel in the Persian Gulf. Others expressed fears were that the Spanish would embargo all English trade with their possessions and that the Spanish marriage for Prince Charles would be hurt. ${ }^{18}$

Worse than the criticism of their fellow merchants for their acts were the increased efforts of the Portuguese to win back the Persian Gulf commerce. Where the Portuguese had enjoyed a haven and a rich commerce, as well as large revenue from license fees, the English had only a feeble trade. The Portuguese repeatedly made fierce attacks on English shipping in India and the Persian Gulf, at times interrupting the flow of trade to Europe. This precarious position in Persia continued throughout the next war with Spain. Only Dutch aid kept the English in Persia through 1625.

The reaction in Europe was what one might expect. When news reached Spain, the court exploded and the English ambassador was much abused. After protests and demands for satisfaction were sent off to England, the council of state and the council of Portugal repeatedly met for the next year or so to discuss what should be done to regain Ormuz. At first there was talk of immediately sending a large fleet to attack Persia and prevent an Anglo-Persian alliance against Goa. Others recommended that alliances be made with the various native princes to externinate the Dutch and English threat. A blockade of the English Channel and English ports until restitution for Ormuz was made was also proposed. Cooler heads talked of winning the English from the strained union of the Dutch and English East India Companies. Then, they proposed an Anglo-Portuguese company be formed to fight the Dutch, and reconquer the territory lost to Persia. 
Until March 1623, the council of Portugal repeatedly urged that a strong fleet be prepared to sail the March Monsoon to retake Ormuz. There was too little time to ready such a fleet for March, however. Talk then shifted to a September fleet, a March 1624 fleet, and so on. Ships were sent out to reinforce the Portuguese holdings in the East, but never in sufficient strength to retake Ormuz. The plans for reconquest were stalled and then consumed in the bureaucratic quagmire of the Spanish state. All too soon there were more pressing matters to consider than the reconquest of Portuguese empire. When the Portuguese regained their independence in 1640 , they were too weak to try any such ventures on their own. ${ }^{19}$

Fortunately for the English ambassador to Spain, Prince Charles and Buckingham arrived in Spain to woo the Infanta. On April 29, 1623, the response of the Prince of Wales to Spanish inquiries about why so little was being done in England was presented to the council of state. The answer of the councilors differed. Many wished to accept the Prince's explanation and sympathize with Charles because his father was not in absolute control of his kingdom. The Count of Gondomar pressed for negotiations on a united company of English and Portuguese merchants. Others called for war to recapture the fortress. ${ }^{20}$

The reaction in England revealed much about the character of James I and the East India Company. Upon receipt of intelligence on the proceedings of the English at Ormuz, the governors decided to cataloque their losses to the Portuguese. This was necessary to justify the acts of the merchants in the East. For the most part, the governors inclined to peaceful trade and conquest horrified them. Yet, since the reports they received talked of much booty and riches to be gained, rather than repudiate the action of their fleet, the governors resolved to make the most of a poor situation.

The Spanish ambassadors pressured James I and complained that they received no justice through the Admiralty Court. James sent word through Secretary Conway to the East India Company on June 30,1623 of the new Spanish claims on Ormuz. The king wanted the company to be prepared to answer all the charges against them.

The company responded by sending the Lord High Admiral, Buckingham, £ 2,000 "to sweeten him for their future occasion," especially in negotiations on Ormuz. ${ }^{21}$ Buckingham informed James I of the company's "generosity." James and Buckingham then told the company that the king would also enjoy a donation. Haqqling over the price of the royal refusal to grant the Spanish claims against the company continued into June of 1624. The Lord High Admiral and the king arqued that the company had taken at least $£ 100,000$ in prizes in the East Indies, including the booty from Ormuz. If the depredations practiced on foreigh shipping were reprisals for damages, then they were legal acts and one-tenth of the spoils was due the Lord Admiral. If the company denied that their actions were reprisals subject to the authority of the Admiralty Courts, their activites could be nothing more than piracy. If the company was quilty of piracy, all responsible faced a fate similar to that of the beheaded Sir Walter Raleigh. The king and Buckingham demanded $£ 10,000$ each to cover their pains for regarding the company's acts as legal reprisals.

When the company refused to pay the demands of the crown, Buckingham arrested the company officers and prohibited its ships from sailing. Buckingham then took the 
matter to Parliament. There the company's supporters suffered under the attacks of its enemies. Bullionists demanded to know how much bullion was exported by the company and wanted a prohibition of all bullion exports. The attack was quieted only after Thomas Mun and Deputy Governor Abbot demonstrated that out of the $£ 400,000$ in goods imported in years when the company was allowed to trade free from interruption, $£ 100,000$ in goods were sold in England and the rest re-exported for a handsome return in goods and bullion. The company resolved to pay the Lord High Admiral and his master their quiet money. ${ }^{22}$ The king then forgot the issue. The Spanish accepted this unfriendly act as a matter of course and, even in later years, regarded James as their best friend in England and a man of peace. Nevertheless, the king's refusal to give the Spanish satisfaction for their claims contributed to war between the two crowns in 1625 .

Such wars were the natural outcome of the competition for wealth and power among European nations in the seventeenth century. Given the refusal of the Iberian crowns to settle the questions of trade in the East, or to meet English demands for permission to trade in areas monopolized by the joint Luso-Spanish crown, the entrance of the English into the East was sure to produce conflict. The conflict between the English and Portuguese in the Arabian Sea-Indian Ocean trading sphere was particularly intense because of the strategic geographic positions occupied by the Lusitanians, and the Portuguese religious, commercial, and political commitments in the region. When the English came to trade in India and then in Persia, their presence constituted a threat to every aspecto of Portuguese life in the East. They offered alternative trading partner for the Eastern principalities then dependent upon the mercies of the Portuguese. As a sea power of some consequence, the armed merchant vessels of the East India Company were viewed by the Portuguese and native princes alike as a balance to Portuguese sea power. This facilitated the entrance of the English into the country trade.

The Portuguese, moreover, were justified in their fear of the English, especially in Persia. When the English went to Persia, they avowed that their aim was to acquire a port there to win the entire silk trade for England, and destroy Portuguese commerce at Ormuz. The Portuguese resisted the English attempts by attacking English shipping and trying to undermine their efforts at the court of Shah Abbas. The Persians played the Europeans against one another to destroy the Portuguese power along their coasts. The total English power in the East was less than that of either the Shah or the Portuguese. The English had sufficient sea power, however, to neutralize the portuguese. The Shah, therefore, used the English desire for trade and emmity towards the Portuguese to bring the English into an alliance against Ormuz. The English did not want to forfeit the Persian trade and joined the Persians against the Portuguese. The superior Persian land forces, the English ships, the lack of supplies, and the inability of the Portuguese to receive fresh supplies and manpower immediately from Goa proved the downfall of Portuguese dominance in the Persian Gulf. The Persians then used all their wiles to prevent the English from becoming too strong, while enticing them with just enough trade to keep them there as a buffer against the Portuguese. 


\section{NOTES}

1 João de Barros, Decadas (Lisboa: Sa da Costa, editôra, 1946), IV, pp.130-179.

${ }^{2}$ Manuel de Faria e Souza, Asia Porguesa, trad. de Isabel Ferreira de Amaral Pereira de Matos e Maris Vitória Garcia Santos Ferreira (1649, rpt. Porto: Livraria Civilização, Editora, 1945), VI, pp.459-462; Don Garcia de Silva y Figueroa, Comentarios de D. Garcia de Silva Figueroa que de parte del rey de España Don Felipe III hizo al rey Xá de Persia (Madrid: La Sociedad de Bibliófilos Españoles, 1903), I, pp.182-183, 239-242, 260-266.

${ }^{3}$ Faria y Sousa, A sia Portuguesa, VI, p.462.

${ }^{4}$ Thomas Man, England's Treasure by Forraign Trade or The Ballance of Our Forraign Trade Is the Rule of Our Treasure (London, 1664) and A Discourse of Trade, From England Unto the East Indies: Answering to Diverse Objections which are Usually Made Against the Same (London, 1621).

${ }^{5}$ Olement R. Markham, editor, The Voyage of Sir James Lancaster, Kt, to the East Indies with Abstracts of Journals and Voyages to the East Indies During the Seventeenth Century, Preserved intthe India Office (London, 1897), pp.120-130, 145-150; William Foster, editor, The Voyage of Thomas Best to the East Indies, 1612-1614 (London: Hakluyt Society, 1934), pp.XXII-XXVII.

${ }^{6}$ See the January 19, 1611 correspondence of Sir J. Digby to Salisbury in Great Britain: Public Record Office, Calendar of State Papers, Colonial Series, East India, China and Japan, 1513-1616 (London: Public Records Office, 1862), pp.233-234.

${ }^{7}$ D.W. Davies, Elizabethans Errant. The Strange Fortunes of Sir Thomas Sherley and His Three Sons as Well in the Duth Wars as in Muscovy, Morocco, Persia, Spain and the Indies (Ithaca, New York: Cornell University Press, 1967), pp.225-242.

${ }^{8}$ Samual Purchas, Hakluyt Posthumus or Purchas His Pilgrims, reprint, Vol. IV (Glasgow: Hames MacLehobe and Sons, 1905), pp.180-203. (This section is the Journal of Walter Payton, who was one of those sailing on the Expedition.)

${ }^{9}$ Silva y Figueroa, Comentarios, Vol. II, pp.135-143.

${ }^{10}$ Purchab, His Pilgrims, Vol. IV, pp.266-280. (Journal of Richard Steele and John Crowther's overland Journey to Ispahan, Persia.)

${ }^{11}$ William Foster, editor, The Embassy of Sir Thomas Roe to the Coast of The Great Mogul, 1615-1619, as Narrated in His Journal and Correspondence (London: Hakluyt Society, 1899), pp.XLVI-LIII, 554-555.

${ }^{12}$ Ibid.: Great Britain: Public Record Office, Colonial Series, 1617-1621, pp.29-30, 45-47, $155-159,198-200$.

${ }^{13}$ Ibid.

${ }^{14}$ Silva y Figueroa, Comentarios, Vol. II, pp.450-45 2 Great Britain: Public Record Office, Colonial Series, $1617-1621$, pp.450-458.

15 "Relations of Ormuz," Purchas, His Pilgrims, X, pp.332-374; also see the numerous notarial records and reports of the proceedings at Khisme and Ormuz contained in Documentação Ultramarina Portuguesa, (Lisboa: Centro de Estustos Históricos Ultramarinos, 1962), II; and in the English merchants' reports to the East India Company calendared in William Foster's The English Factories in India, 1622-1623: A Calendar of Documents in the India Office and British Museum (Oxford: At the Clarendon Press, 1908).

${ }^{16}$ The Fleets of Defense were part of the operations of the United Anglo-Dutch East India Companies that resulted from the 1619 treaty. While these fleets officially were for defense, more often than not, they engaged in purely piratical acts against Spanish, Portuguese, and native shipping in the East.

${ }^{17}$ Silva y Figueroa, Comentarios, Vol. II, pp.584-587. 
18 Foster, The English Factories, pp.164-165, 186, 200-201, 223, 227, 312, 313.

${ }^{19}$ Documentação Ultramarina Portuguesa, Vol. II, pp.308-315, 356, 366-367, 402-403.

${ }^{20}$ Ibid., pp.434-438.

${ }^{21}$ Great Britain: Public Record Office, Colonial Series, 1622-1624, pp.120-124.

${ }^{22}$ Ibid., pp.LXVII-LXIX, 125-135. 